\title{
Ambiances
}

anbiances Environnement sensible, architecture et espace urbain Redécouvertes | 2020

\section{For an aesthetics of ambiance}

Pour une esthétique des ambiances

\section{Jean-François Augoyard}

Translator. Harry Foster

\section{OpenEdition}

\section{Journals}

Electronic version

URL: http://journals.openedition.org/ambiances/3136

DOI: 10.4000/ambiances.3136

ISSN: 2266-839X

Publisher:

Direction Générale des Patrimoines - DAPA - MCC, UMR 1563 - Ambiances Architectures Urbanités (AAU)

\section{Electronic reference}

Jean-François Augoyard, «For an aesthetics of ambiance », Ambiances [Online], Rediscovering, Online since 13 October 2020, connection on 15 October 2020. URL : http://journals.openedition.org/ ambiances/3136; DOI : https://doi.org/10.4000/ambiances.3136

This text was automatically generated on 15 October 2020

\section{(c) (i) (9)}

Ambiances is licensed under a Creative Commons Attribution-NonCommercial-NoDerivatives 4.0 International License. 


\title{
For an aesthetics of ambiance
}

\author{
Pour une esthétique des ambiances
}

Jean-François Augoyard

Translation : Harry Foster

\section{REFERENCES}

Augoyard, Jean-François. 2004. “Vers une esthétique des ambiances”. In: Amphoux, Pascal; Thibaud, Jean-Paul \& Chelkoff, Grégoire (eds.). Ambiances en débats. Bernin: À la Croisée (Collection Ambiances, Ambiance). p. 17-30.

\section{EDITOR'S NOTE}

Translation of a revised article initially published in French in 2004.

Traduction d'un article revisé, initialement publié en français en 2004.

\section{The necessary, yet ticklish concept of ambiance ${ }^{1}$}

1 In the past 30 years what is known as 'maitrise des ambiances' (atmosphere control) has become a mainstream subject in teaching at French schools of architecture (Ecoles Nationales Supérieures d'Architecture). Among the perceptible qualities of the architectural and urban environment - light, sound, air flow, tactile matter, and systems affecting our movement and posture - some have been prioritized in instruction on project design. The atmospheres such techniques seek to control mainly relate to acoustics, lighting and heating. In these three fields a stock of learning has built up which now serves as the basis for regulations and standards, inspires efficient techniques and, lastly, induces strategies for creating comfort.

2 The fairly recent boom in these sciences applied to architecture has obviously made an important contribution to the project-design process. In this application-driven 
rationale, scientific learning reaches down to the level of technical demand. Faculty members in the three fields concerned act as experts 'serving the project'. But this laudable attitude overlooks the key question of how project methodology changes our understanding of ambiance. With regard to epistemology, is there an 'upward' movement by which scientific and technical learning may be brought back into perspective? Does the 'application' go so far as to confront a project's complexity? And what becomes of these sciences in a project dynamic which synthesizes its strands rather than separating them? No doubt lecturers and researchers working on acoustics, heating and lighting capitalize on experience gained from practical application of theoretical learning, enabling them to rank constraints and select the most suitable systems. But is it easy to gain acceptance for the idea that a proven qualitative data can counterbalance a measurable quantity? More broadly, another question concerns the entire field of ambiance: whereas the project-oriented method is based on integrating disparate data, what have we to offer at present but a collection of hermetically sealed disciplines? Whereas an architect produces an ambiance, we are suggesting that he or she should connect up ambiances, one thermal, another acoustic, and so on.

Because it is applied to architecture, research on ambiances currently seems to face a dual problem: how to open up to complexity (essential nature of the project); and how to retain its unity or, at least, the horizontal nature of the sectoral learning at stake. The two main meanings of the French word 'ambiance', as it is most usually defined "1- the material and moral atmosphere surrounding a place or person; 2-, the physical elements and devices which make up an ambiance" - refer us back to the large opening of the objective and subjective dimensions as well as of their paradoxical unity. This elementary definition raises a challenge. Given our current inability to understand and control an ambiance, we need to engage in a fundamental process, starting by querying the word itself.

4 The usage of the notion of environment, which has been much abused, has a major drawback for scientific disciplines related to the built space. It is almost impossible to integrate in a project, other than as a regulatory constraint. It presupposes an attitude which grasps the context as a given state and not as a process. As a result, the whole creative, dynamic dimension of architectural production is foreign to it. The notion of architectural or urban ambiances provides a much larger opening, and I would like to demonstrate its potential and reveal its promise. Light, heat or sound ambiances are at one and the same time sensory phenomena and produced phenomena. In the professional and pedagogical field of sciences applied to architecture, the notion of ambiance is closely associated with the notion of control - as in "atmosphere control" lessons. In fact, an understanding of ambiance is based on three components: input from science and technology; input from learning on usage and everyday representation; and input from art.

\section{Part of Art}

5 The first field keeps pace with advances in instrumentation and modelling achieved by applied physics. The second field evolves with new attitudes to the observable in human and social science. So is art some sort of black box? What does art contribute to our understanding of ambiance? 
6 The production of ambiances involves art and know-how in two ways: all too often implicitly, in any ordinary architectural act; and as an expert skill in ongoing work on the sensory aspects of urban development. In the practice of any architectural or planning project, a master plan, a decision on form or a choice of material necessarily entails light, sound, heat and/or tactile effects the overall impact of which is usually only controlled by the limits set by regulatory technical obligations. The rest anything that cannot be considered an active nuisance - is almost always ignored, dismissed as insignificant or covered up by some aesthetic judgement restricted to the visible appearance. The rest is supposed to be an unknown land, and as such unpredictable, the good and ill effects of ambiances only appearing once construction is complete ${ }^{2}$.

7 So, as a result of this magical conduct, but also the obligations of everyday building management, there is a second field in which ambiances are produced. Though art plays a part here too, but its share is unevenly spread. In a majority of cases urban ambiances are addressed and managed by a wide variety of actors, most of whom are more inclined to reproduce existing know-how than to do anything genuinely creative: typically a firm fitting outside insulation on old buildings, a municipal worker installing lamp-posts, a sound engineer setting up a temporary public address system for a boot sale, or a transport operator which turns a blind eye to buskers.

This is very different from the artistic ability of the new creative designers of what has ended up being called 'urban scenography'. Work dramatizing the urban scene with sound and light was once the preserve of land-art practitioners such as Christo or Max Neuhaus. They are now an integral part of the overall process of urban development to which they bring imagination and a sense of spectacle ${ }^{3}$. Looking specifically at France we may cite several already historic references. Nicolas Frize transformed the practice of composers in residence by focussing directly on the relevant space, with the population of the host town. Laurent Fachard transposed the aesthetics of his stagelighting mentor Henri Alekan for use on facades and historical monuments, rejuvenating the city with light ${ }^{4}$.

The concept of architectural ambiances has greater ease integrating this type of artistic input, a know-how focused on producing the urban space which is largely foreign to the semantics of the environment. On the other hand, the fact that the core concept remains resolutely plural - as in ambiances - reflects a far from negligible handicap. In the present state of our knowledge, to speak of urban ambiance corresponds to nothing that can be analysed precisely, apart from the succession of sensory registers, each sense involving specific rationales for observation and specific tools. Nor is there any scope for interdisciplinary confrontation. We have accumulated knowledge on heat ambiance, sound ambiance, light ambiance, even odour ambiance - in which people are beginning to take an interest, but we still lack a trans-sensory theory covering the various disciplines concerned by the perception and the variety of sensations. This cannot be replaced by some work on binary interactions in physiology and ergonomics, nor yet by the celebrated though hypothetical correspondence theory, nor indeed by the existence of general explanatory models thought to be applicable to all, or almost all, the senses 5 . 


\section{For a general aesthetics of ambiance}

10 As applied to planning and built space, the concept of ambiance may be given a more specific formal definition, which I propose to express in the following terms.

11 A set of localized phenomena may exist as ambiance if it fulfils four conditions.

1. The physical signals from the situation can be identified, isolated and analysed.

2. These signals interact with:

- the perception, emotions and action of subjects;

- social and cultural representation.

3. The phenomena make up a built spatial assembly (architectonic construction and/or perceptive construction).

4. The complex [comprising signals, percepts and representations] can be expressed (scope for accessing its representation by experts and/or users).

12 This definition suggests scope for moving from a disparate, plural field of research devoted to ambiances to a general theory of architectural and urban ambiance. To do so, it seems to me that we need to develop two main research themes:

1. looking for models of intelligibility capable of integrating various ambiances (light, sound, heat, smell and so on), while allowing for both qualitative and quantitative dimensions;

2. developing the five sectors of analysis on which the least work has so far been done: interdisciplinary methodology; in situ perception; intersensoriality; social representations of ambiance; urban management, and technical and economic changes in atmosphere control.

13 For the first theme, I would suggest developing a general aesthetics of ambiance, not that this route is the only one available, but as well as giving priority to sensoriality, intuition and the imagination it opens onto the creative domain, which plays an essential part in architecture worthy of the name. It should however be emphasized that this aesthetics would not be restricted to simply theorizing the reception of artistic forms but would be rehabilitated in its completeness, in other words reaching as far as its sensory roots and its ordinary (non-artistic) exercise. This theme would also involve paying fresh attention to several currently disregarded sectors, the very same which are covered by the second research theme cited above.

\section{An aesthetics of sensory forms: the aesthesic level}

Since the Renaissance, much as other forms of learning with a rational basis, architecture has been largely dominated by the visual ${ }^{6}$. Sight has become the predominant sense, not only by rooting design in drawing, but also fundamentally connoting the language of analysis and directing the rhetoric of architectural conception ${ }^{7}$. Seeing is self-evident. From plans to models, from the drawing board to the building site, the production of built forms depends so much on vision that we sometimes even forget its hegemony.

Returning to the primal state of things, with respect to perception, research on architectural ambiances encounters a collection of signals and sensory stimuli all with equal rights. It has every scientific reason to query the nature of an invisible form, following the rationale of hearing or smell to describe an inhabited territory, and 
wonder how a heat, olfactive or aerodynamic landscape composition might appear8 After all, there is no need for such a space - be it defined by sound, fragrance or heat to be orthogonal. Nor is there necessarily any congruence between its visual, sonic and tactile limits, each being of a very different nature. The spatial reference, as defined by Newtonian characteristics, loses its value for the purposes of explanation when dealing with sensory processes other than seeing. Furthermore, it can be demonstrated that even the visible is not entirely subject to Cartesian spatiality (Augoyard, 1995b). At the same time, it is hard to imagine representations of touch, heat and fragrance which would comply with the rationale specific to each of these sensations. How is one to convince an architect that a sonic form is primarily a matter of time? 'And how can I draw that,' she might ask.

Given these various forms of resistance, it is apparent how deeply rooted the visual metaphor is in the way we conceive the built space. Is it illusory to want to re-establish the 'balance of the senses', to which vernacular architecture - or intuitive building not subject to the hegemony of sight - seem to have paid more attention ${ }^{9}$ ? At the very least we need to disturb the mindsets of architects and planners who too often forget the existence of the other sensorialities. Rehabilitating the currently 'minor' senses involves three tasks. The first concerns criticism of the stereotypes which govern the definition of briefs. The second must work to modify cognitive attitudes to the built space. The third brings into play the architect's creative imagination.

In building practice, we need to demonstrate, citing firm evidence, the possibility and formal, social and economic benefits of preventive integration of all the components of comfort, at the brief-definition stage. The economic and social cost of bad workmanship, which damages the health and well-being of occupants, always exceeds the projected and real extra cost of building procedures. The argument often cited by those in charge of architectural or planning projects, for not going below the lower limit of comfort imposed by regulations, is based on a rationale of superfluous additions or systematically over-specified materials. No thought is given to the effectiveness of clever organization of space or shapes designed in such way as to encourage such and such an acoustic or thermal effect.

But how could this be achieved? It is the task of information and, to an even greater extent, education. So it is a long-term undertaking, because it involves changing cognitive attitudes forged in the Classical age which impregnate not only architectural studies but also the entire curriculum ${ }^{10}$. For example, in a strictly theoretic modality, there is little point in learning the properties of the sound environment. To genuinely understand what should be called a 'hearing of the world', with well rooted knowledge we need a pedagogy of listening, which involves reforming our acquired auditory habits, which are most of the time actually attitudes of not listening. Without this propedeutics, there is no hope that when the morphology of the built space emerges the architect will be able to think in terms of sonic form in a manner comparable to visible form.

Without this incorporated sensory experience, which would need to be applied to each of the sensory channels, the sonic, aerodynamic, olfactive and tactile qualities of a space will never be anything more than additions to the visibility of the created form; and the imprint of the forgotten senses ${ }^{11}$ will never be pregnant, nor contribute effectively to the production of form. The third task of research is to facilitate the ordinary exercise of the constructive imagination, that is just as inventive with regard 
to hearing, movement, smelling and relating to the air, as it is with regard to seeing. This deliberate, much needed polysensory qualification for all types of architecture cannot simply be derived from the specialist know-how used in exceptional architectural undertakings, such as opera houses, auditoriums, exhibition centres or experimental solar houses. The approach to building deployed in everyday architecture must invent, in keeping with its own economy, suitable processes and systems for creating comfort ${ }^{12}$. An ethno-historical investigation is also needed of intuitive and inventive knowledge and know-how born of natural but also cultural necessity to master the components of comfort in everyday architecture ${ }^{13}$.

\section{An interdisciplinary aesthetics: the ecological level}

Being a cumulative form of learning, architecture is by definition pluridisciplinary, whether the various types of knowledge simply coexist or are confronted with one another, adjusted to suit a common epistemic background, which is less usual. Yet the labour of design present in any architectural project demands genuine interdisciplinarity, in other words a competitive, dialectic confrontation of different sorts of learning and processes.

So what has the practitioner to say on this topic? That an accomplished project is a matter of experience, dexterity and trade-offs between opposing constraints, with a random, event-related side which depends on the project's story. That the process of updating the epistemic background of architecture was completed long ago. Light has gradually been cast on it, at least in part, since Romanticism, each time an author has queried the essence of this atypical 'art form' which combines function and beauty so interdependently. Much less attention has been paid to its cognitive workings. What is the nature of the mysterious unity which ties together very different forms of knowledge in the act of architecture, and which, in addition, articulates both learning and know-how? Although architecturology is still under construction, we ought to be grateful to Philippe Boudon for deliberately focusing the question on epistemology.

Among the questions about architecture which have thus been restated, one of the most important is to know how the project process can link up all the learning accumulated on architecture. The ecological question which forces us to address the relations between the human and physical dimensions of situated phenomena is similar, in this respect, to the architectural question. It thus emerges that the descriptive, taxonomic undertaking applied to architectural forms, as typomorphological species, is far from being sufficient to serve as the exclusive basis of architecturological learning. As with memory, architecture is not just a polypary of images. Just setting aside the field of the visible is enough for the types and classes to lose their relevance ${ }^{14}$.

The current growth in research by our laboratory (Mixed Research CNRS Unit 1563, Architectural and Urban Ambiances) tends to show that architectural morphology is based on various forms of structural interdependence between built, perceived and represented form (Chelkoff, 2004). There is no way of explaining the basis for one of these modalities without referring to the others. There is nothing mysterious about the three operators in this modal conjunction. They are the perceptible physical signal; all the standards, rules and codes; and finally the instrumentation, functions and usages associated with the built form. Ongoing work on studying the complex, interdependent 
working of these operators should help to gain a better understanding not only of the nature of the sensory environment, but more largely of the interdisciplinary processes involved in the act of producing built space.

\section{An aesthetics of usage: the rhetorical level}

Understanding the practices and usages of inhabited space has become a key theme in urban and architectural research in the past 40 years. This work has exerted considerable methodological influence on observation of the perceptible environment, as discussed above. In return new understanding of architectural ambiances should contribute to a better grasp of how architecture is used. This may happen in two ways: on the one hand by restoring the function of physical factors in the perception of space; and on the other by highlighting the instrumentation of perceptual constructions and in situ social cohesion.

We may recall that research in France has treated the question of the perception of built space in three very distinct ways in the past 50 years. Either by developing an experimental psychology, often too eager to shrug off its behaviourist origins by looking for openings in comprehensive psychosociology ${ }^{15}$. Or by developing the phenomenological seam which was explored with mixed fortunes by architectural and planning researchers. However appealing it may be, the use of the logical and verbal organum of the post-Husserlian field cannot dispense with the patient labour of reduction, the meticulous attention paid to objects without which any phenomenological enterprise loses contact with reality ${ }^{16}$. Or, lastly through certain endeavours of urban sociology focusing on collective representations of objects such as landscape, habitat, public space and heritage.

Ambiance-oriented research has no pretension to reconcile these different currents, in which the strength of methods and interest of results are due, in part, to the specificity of the standpoint adopted and, often, to a deliberately antagonistic stance. But, as we have emphasized, the observer of an in situ environmental phenomenon must make allowance for the physical signal, the processing imposed by perception, and the collective component. In other words he or she must come to terms with the problematic articulations which other types of research overlook.

So, in turning against the physical substantialism entailed by a reductive behaviourism which attached no causal value to collective forces, urban sociology re-established and rightly so - the autonomy of social causalities. The downside is the enduring wariness of anything which touches on the materiality of space. But to persist in this attitude is to forget that the behavioural sciences have changed in the past 20 years. After all the physiology of perception has told us, increasingly often, that the physical environment is no more nor less than a series of properties offered up to the dynamic of our perceptive constructions (Berthoz, 1997)?

Furthermore, the development of a sociological rationale, at the heart of the urban phenomenon, could end up idealizing the notion of social cohesion. As if the analytic register had ended up by creating conditions for everyday existence, as if learning, forgetting the senses, had produced a reality stripped of all sensation. Yet social interaction would have absolutely no effect without the sensory-motor instrumentation which incorporates it. How can anyone think that sensory marks will 
have no effect on the 'message', except as a hylomorphism which we can no longer admit and which elementary observation contradicts ${ }^{17}$ ?

Research on urban ambiance must consequently address the physical signal not only as a means of perceiving space, but as an instrument of social cohesion in space. It should develop this investigation in two complementary directions. The question of how the social can also be sensory is the focus of the praxeology of perception, and of the observation - which has so far made little progress - of the instrumentation of social relations (Thibaud, 2004). Meanwhile the question of how the sensory can also be social is the focus of the development of the fundamental aesthetics, reaching out in two directions, also little explored: the aesthetic experience as action and as shared knowhow.

Architecture and towns are not just objects. Their sensory effects act at the centre of a knot tying together perception and action, form and function, the individual and the collective. How then can architects and planners think about the way a built space is used without knowing how it is 'lived' by the residents who 'reconstruct' it? We may suppose that with progress in work on the sensory environment our understanding of the relation between the end-user of a space, and the professional or expert, may change slightly. The end-user's sensory environment will no longer only be considered as an object for consumption, or perhaps contemplation, and action, in the sense of protest. Knowledge of the modalities of everyday practice is becoming a priority. How can we make do with received conceptual tools and explanatory models? The task of updating the multiple forms of interdependence requires paradigmatic tools such as the effect, the motif, the ambiant and the transcript ${ }^{18}$ but also the procedures for clarifying and simulating made possible by digital modelling. With this sort of descriptor we shall be able accurately to develop the rhetoric of ordinary action which I have sought since my earliest work ${ }^{19}$.

\section{An aesthetics of shared reception-creation}

31 A great deal of work has been done on architecture from the perspective of art history, but very little on its aesthetic side, as Baumgarten understood it: the theory of beauty through an self-sufficient sensibility ${ }^{20}$. It seems easier to deal with the production of built forms, to classify categories, styles and schools, than it is to analyse how an architectural or urban work was received. The brief, partial pages in Hegel's Aesthetics fit into the larger framework of a theory of the symbolic hierarchy of forms, given their prescriptive nature. Few authors have ventured into the perception of architecture, and those who have did so with the intention of criticising prior judgements inspired by taste, and to reform the representations of the urban scene (Camillo Sitte) or monuments (Aloïs Riegl). Some psychologists and philosophers of art - such as Ervin Panofsky, Pierre Francastel, Ernst Gombrich or indeed, Nelson Goodman - made valuable comments on the connection between perceptive organization and the structures of representation of architectural works. Similarly, with regard to the meaning of architecture, there are theories as famous as those formulated by Venturi or Christian Norberg-Schultz of which the phenomenological vein brings us closer to feeling. But more psycho-sociological approaches, carefully underpinned by semiological interpretation of user representations, rather than direct observation of the sensory experience ${ }^{21}$, go no further in their exploration of the sensory modalities of 
the perception of built form. Between the aesthetic experience of the work of architecture and sensory experience of the built environment, there remains a gaping hiatus.

To what is this difficulty due? The first reason is no doubt the fact that architecture reaches beyond art properly speaking in two ways, for, to retain the Vitruvian triptych, it adds to beauty (venustas), the only focus of artistic contemplation, building techniques (firmitas) and functionality of use (commoditas). It is consequently unlikely that much progress will be made with architectural aesthetics until these two obstacles have been overcome. On the one hand what is the relation between formal creation and technology. On the other, what is the relation between built form and inhabited form?

The built environment confronts two questions central to contemporary debate on aesthetics, in the following way: to know where the borders of the artistic run; to understand the role of the perceiving subject. Few tools are available as yet in the field of general aesthetics to elucidate the contradictory articulation between form and function. On the one hand the invaluable German aesthetics movement, which spans the past two centuries, provides a set of meaningful hypotheses in this direction ${ }^{22}$. On the other pragmatism ${ }^{23}$ as applied to the spectator has made fundamental observations on sensory and cultural reception. These two apparently different approaches do however have one vital point in common: all analysis converges on questions concerning contextualized perceptual organization. What forms of rationale are specific to each sense? How is intersensoriality articulated, enabling us to obtain unity of form? Debate on these questions is underpinned by a common hypothesis: our relation with the sensory and formal environment should be thought of as an exchange, a constructive circulation between given and configured, sensed and acted, perceptible and representable, individual and collective.

Starting from this elementary architectural aesthetics, the built form can be considered in four respects. It is a bundle of physical properties distinguished according to the nature of each type of signal. It is a situated sensory configuration. It is the expression of a culture of experts combining function, art and technology. It is the expressionreception of a culture of resident-users.

\section{Four questions for the theory and practical analysis of architectural ambiances}

35 In the light of the preceding indications, which it will summarize, we may suggest a third definition of ambiance which brings us back to the practice of architectural design as an object for analysis but also as a productive method for working. It will be of a dynamic or genetic nature in a dual sense: it specifies the conditions for the existence of ambiance; it engenders the driving issues for research into architectural ambiances with the prime concern of helping project practice.

What in concrete terms produces an architectural ambiance?

1. It is a technical device linked to built forms.

2. It is a perceptual whole bringing together subjective and objective components, and represented as atmosphere, climate, physical and human milieu.

From an empirical or operational point of view it is consequently easy to define the ambiance of a place. Nor is there any shortage of techniques for doing so. The 
integrating talent of spatial designers may be extremely uneven, but a built structure never fails to produce an atmosphere of some sort. But the simplicity of this practical content conceals some fearsome pitfalls. First of all the two halves of the definition do not connect. Either the unity of ambiance is due to the genius of the designer, the talent of the technician, dispensing with the need for further analysis of, for example, the context of production or provision for ordinary forms of usage. It is the prerogative of art and the arbitrary nature of formal decisions between the prince and the artist, or the ambiance-weaver. Or, in situations of research, learning and help with design, it is crucial to determine the main force of attraction in the complex constellation which makes up ambiance. The main difficulty is in the analytical unity of an ambiance's components and the rigorous understanding of the relations between the two halves of the definition.

To get round this source of perplexity, I suggest four programme-focused questions which may give rise to a general theory of architectural and urban ambiances.

1. How does a diverse collection of signals, percepts and collective representations make an ambiance? What connects the 'objective' to the 'subjective'? What method of observation can be deduced from this?

2. How are the various sensory components of a place's ambiance connected? What is a qualified space? Should we think of ambiance in the singular or plural? Are there any universals for analysing and understanding all the forms of ambiance? If so, what is their nature? Are they theoretical concepts, categories, paradigms or operational concepts?

3. What makes an architectural ambiance? Surely the opposition between expert and end-user requires the active and perceptive roles to be redistributed? What common ground is there between a technician's and a user's actions?

4. How are we to control ambiance, torn between the requirements of standards, technical constraints and creative impulse? Does analysis of ambiance throw new light on the interdependence of the three relations which characterize architectural production: comfort and beauty; function and symbol; conformity and anomie (creation)? Which theory, which models enable us to conceptualize the integration of these three components technology, standards and art - in the production of ambiances?

\section{BIBLIOGRAPHY}

Augoyard, Jean-François. 1979. Pas à pas. Essai sur les cheminements quotidiens en milieu urbain. Paris: Le Seuil (republished by Editions À la Croisée, Bernin, 2010, with prefaces by Françoise Choay and Yves Winkin). Transl: (2007) Step by Step. An essay in Everyday Walks in an Urban Setting (translated by David Ames Curtis). Minneapolis: Minnesota University Press.

Augoyard, Jean-François. 1995a. L'environnement sensible et les ambiances architecturales.

L'espace géographique. 4. p. 302-317.

Augoyard, Jean-François. 1995b. La vue est-elle souveraine dans l'esthétique paysagère ? Le Débat. 65. p. 51-59. Or : La vue est-elle souveraine dans l'esthétique paysagère ? In: Roger, Alain (ed.) La théorie du paysage en France (1974-1994). Seyssel: Ed Champ-Vallon. p. 334-345. 
Augoyard, Jean-François. 1995c. La sonorizacion antropologica del lugar. In: Amerlinck de Bontempo, Mari-José (ed.). Hacia una antropologia arquitectonica. Jalisco, Mexico: Ed. Universidad de Guadalajara (Colleccion Jornadas Academicas). p. 205-219.

Augoyard, Jean-François. 1998. Eléments pour une théorie des ambiances architecturales et urbaines. Les Cahiers de la Recherche Architecturale. $n^{\circ}$ 42/43, p. 7-23.

Augoyard, Jean-François. 2004. Vers une esthétique des ambiances. In: Amphoux, Pascal; Thibaud, Jean-Paul \& Chelkoff, Grégoire (eds.). Ambiances en débats. Bernin: A la Croisée (Collection Ambiances, Ambiance). p. 17-30.

Augoyard, Jean-François \& Torgue, Henry (eds.) 2006. Sonic Experience. A Guide to Everyday Sounds (translated by Andra McCartney \& David Paquette). Montreal: McGill Queen's University Press.

Augoyard, Jean-François; Balaÿ, Olivier \& Chelkoff, Grégoire. 1982. Sonorité, Sociabilité, Urbanité. Méthode pour l'établissement d'un répertoire des effets sonores en milieu urbain. Grenoble: Cresson.

Berthoz, Alain. 1997. Le sens du mouvement. Paris: Odile Jacob.

Chelkoff, Grégoire. 2004. L'hypothèse des formants. In: Pascal Amphoux, Jean-Paul Thibaud, Grégoire Chelkoff (eds.). Ambiances en débats. Bernin: A la Croisée. (Collection Ambiances, Ambiance). p. 55-69.

Dumaurier, Elizabeth. 1992. Psychologie expérimentale de la perception. Paris: PUF.

Hall, Edward T. 1966. The Hidden Dimension. New York: Doubleday.

Fiori, Sandra. 2000. Réinvestir l'espace nocturne, les concepteurs lumière. Les Annales de la Recherche Urbaine. $\mathrm{n}^{\circ}$ 87. p. 73-80.

Fiori, Sandra. 2001. La représentation graphique dans la conception du projet d'éclairage urbain. (PhD thesis directed by Jean-François Augoyard, Cresson \& Ecole Polytechnique de l'Université de Nantes). Nantes.

Lefevbre, Henri. 1958 [1947], 1961, 1981. Critique de la vie quotidienne (3 volumes). Paris: L’Arche. Lefevbre, Henri. 1974. La production de l'espace, Anthropos, transl. 1991: The Production of Space, N. Donaldson-Smith trans., Oxford: Basil Blackwell.

Moles, Abraham. 1972. Psychologie de l'espace (en collaboration avec Élisabeth Rohmer). Paris: Casterman.

Moles, Abraham. 1976. Micropsychologie et vie quotidienne (en collaboration avec Élisabeth Rohmer). Paris: Denoël.

Moles, Abraham.1982. Labyrinthes du vécu. Paris: Klincksieck.

Mosser, Sophie. 2008. La fabrique des lumières urbaines. Bernin: A la Croisée (Collection Ambiances, Ambiance).

Ninio, Jacques. 1989. L'empreinte des sens. Paris: Odile Jacob/Seuil.

Ostrovetsky, Sylvia. 1983. L'imaginaire bâtisseur. Paris: Librairie des Méridiens.

Panerai, Philippe \& Tatutesco, Dan. 1983. Diversité sonore et formes urbaines, Paris: ADROS/UP3

(2 volumes).

Sansot, Pierre. 2004 [1971]. Poétique de la ville. Paris: Payot.

Segaud, Marion. 1988. Esquisse d'une sociologie du goût en architecture. (PhD thesis directed by François Gresle, Université de Nanterre). Nanterre. 
Thibaud, Jean-Paul. 2004. Une approche pragmatique des ambiances. In: Amphoux, Pascal; Thibaud, Jean-Paul \& Chelkoff, Grégoire (eds.). Ambiances en débats. Bernin: A la Croisée (Collection Ambiances, Ambiance). p. 145-161.

Tschumi, Bernard. 1996. Architecture and Disjunctions: Collected Essays 1975-1990. London: MIT Press.

\section{NOTES}

1. This text was previously published in French (Augoyard, 2004) and has been revised in 2013 for this English version. It focuses on my personal position on the theory of ambiances. Cf. Augoyard (1995a, 1998).

2. This attitude is obviously not just a defensive mechanism, but none of the explanations habitually cited, including the one relating to project economics, stands up to close examination. The shortcomings of training and the dissemination of up-to-date knowledge on this subject prompted several french research laboratories (Cerma Cresson, Isitem, Lash, CSTB) to set up a doctoral course on "Ambiances architecturales et urbaines" in 1992.

3. Instances of towns planning well lit urbanism are now commonplance, witness the Plan Lumière in Lyon, which has existed for the past 20 years and combines comfort with function and safety.

4. Many light artists or designers have worked on the urban environment in the past 15 years, notably Yan Kersale and Louis Clair, in France, but numerous initiatives have taken shape elsewhere. For in-depth study see: Sophie Mosser (2008) and the ground-breaking PhD thesis by Sandra Fiori (2001). See also Sandra Fiori (2000).

5. Key Gestalt theory concepts such as the figure and the background are still much more pertinent for vision than for hearing.

6. It seems hardly necessary to point out that panoptism, in the epistemological sense, found in the Renaissance the conditions for rapid, widespread propagation in art, technology and literature, as demonstrated by authors as different as Rudolf Arneihm, Eugenio Garin, Ervin Panofsky, Ernst Gombrich, Marshall MacLuhan and Michael Baxandall, but the cultural predominance of the visual in the west is rooted in Mediterranean antiquity. The history of this remarkable cultural construct is currently the focus of various studies, in particular on the theme of landscape vision.

7. Regarding the practical rationale of design in planning and architecture, which emerged as a rhetoric, see our analysis and the comparative table in the annex of Pas à pas (Augoyard, 1979).

8. This approach supposes a sensory immanentism of thought. See our discussion of this hypothesis: Augoyard (1995c).

9. This was one of the questions raised at the symposium, Au-delà du paysage moderne, organized by the research association at Ecole des Hautes Etudes en Sciences Sociales, headed in 1990 by Augustin Berque, Paris, Centre Pompidou (Augoyard, 1995b).

10. This should be apparent from structural analysis of the modalities of language used in the didactic injonctions and guidelines we receive even in the early years of schooling. The visual connotation is predominant in verbs, concepts and descriptive adjectives, even in reference to the senses of hearing, smell and touch.

11. L'empreinte des sens is the title of a review of knowledge at the interface between physiology and psychology. Its author, Jacques Ninio (1989) discusses in depth the force of 'perceptive reason'. Also a more recent work by Alain Berthoz (1997).

12. See also the interesting experiment with detached houses, the Maisons des cinq sens, built by L'Effort Rémois about 20 years ago.

13. This is one of the key themes of the international network devoted to "The sound quality of inhabited spaces", operated by Cresson since 1991. 
14. An interesting attempt was made in 1980 by an acoustician and an architect-researcher to test typo-morphological relevance with regard to sound. But the application of types and ratios of scale is only valid for a dwelling with a closed form (typically built round a central courtyard) and only with regard to the insulation coefficient. Otherwise sound phenomena do not correspond to the separations and insertions, used for purposes of classification and proposed by architectural typo-morphology. See Panerai \& Tatutesco (1983). Concerning this critical analysis see also Augoyard et alii (1982).

15. The last summary proposed by Elizabeth Dumaurier, much regretted, was exemplary in this sense. See Dumaurier (1992).

16. It is worth noting that the most ambitious attempts at phenomenonological analysis of perception of built space were made in the 1960-70s by authors of pluralist theoretical inspiration: Henri Lefebvre $(1958,1961,1974,1981)$ never entirely forgetting his Marxist influences; Abraham Moles (1972, 1976, 1982), always very up-to-date with experimental psychology, from which he takes several explanatory models. Unfortunately urban phenomenonologists who are genuinely attentive to things and people are few and far between. In this respect, there is little to compare with the work of Pierre Sansot (2004).

17. On account of the immanence of the sensory in social interaction the figure of the stranger is perceived with very different meanings and values depending on the sensory marker: sight, hearing, smell, touch, etc. This fruitful idea, setting aside the necessary adjustments, was raised by Edward T. Hall (1966).

18. This work on paradigms was carried out in particular as part of collaboration between the two teams Cresson and Cerma (n.cit.). The notion of a transcript, adopted by Cerma, was first proposed by the architect Bernard Tschumi (1996). The notion of Sonic Effect accurately developed by Cresson since 1980, is probably a model of analysing interdependences between spatial, physical and human forms, and between theoretical approach and common practices (Augoyard \& Torgue, 2006).

19. Augoyard $(1979,2010)$; The books of the "Ambiances, ambiance" collection edited by A la Croisée are now available at https://aau.archi.fr/cresson/ressources-documentaires/.

20. Would not know how to hold place count of publications which under the name of "esthetics of the architecture" describe the formal characters of architectures given, rightly or wrongly, as masterpieces to be classified. Again, it is the question of the style that prevails, not that of the esthetic experience of the user. We can put in the same category the arguments of architectural programs which decree in an apodictic way the rustic character, the modernity, the transparency, or the urbanity of buildings, avoiding carefully to evoke the predictable sensitive effects in everyday life.

21. See Sylvia Ostrovetsky's semiotics of vernacular styles (Ostrovetsky, 1983) and Marion Segaud's notion of 'ordinary aesthetic competency' (Segaud, 1988).

22. The Bauhaus aesthetics may be considered to have inherited a great deal from this current.

23. Study of the rationale of action, or the manners of doing. This spectator-based pragmatism was developed by the Prague School, the Konstanz School, the Warburg Institute and carried on in more recent work focusing on the relativistic dimension of aesthetic conduct (Nelson Goodman, George Dickie, Arthur Danto, Jean-Marie Schaefer, Gérard Genette). 


\section{ABSTRACTS}

Why an aesthetics of ambiances? The answer to this question if far from being solely theoretical. It is associated with my personal career in research and academic teaching since the 1980s.

On the one hand, observing everyday ethos, through walks, landscape sensitivity, sound practices, the reception of architecture and street arts have revealed the ambiance as an essential way to question the substance of what is unseen, the nature of the background to the lived environment.

On the other hand, throughout my classes and aesthetics seminars in urban planning and architecture, "art's place" in professions dominated by function forced me to rethink aesthetics as freed from its artistic imperative and digging into its more universal sensitive and atmospheric foundations.

This paper reviews an aesthetics of ambiances that is currently being built, working on four levels. At the aesthetic level: what is the imperceptible? What role do non-visible forms play? At the epistemic level: how do we integrate the relevant knowledge that is still too exclusive? At the rhetorical level: how do the components of an ambiance organise themselves, and how can we name the configurations? At the level of aesthetic competence: who makes an ambiance? How are creation and reception divided?

Pourquoi une esthétique des ambiances? La réponse est loin d'être simplement théorétique. Elle est chevillée à mon parcours personnel de recherche et d'enseignement universitaire depuis les années 80 .

D'un côté, l'observation de l'ethos quotidien, à travers la marche, la sensibilité paysagère, les pratiques sonores, la réception de l'architecture et des arts de la rue ont fait apparaitre l'ambiance comme une façon essentielle d'interroger la substance de l'inaperçu, la nature de l'arrière fond du monde vécu.

De l'autre, au gré de mes cours et séminaires d'esthétique en urbanisme et architecture, la question de "la part de l'art » dans les métiers asservis à la fonctionnalité poussait à repenser une esthétique libérée de son impératif artistique et plongeant dans des fondements sensibles et atmosphériques plus universels?

Cet article fait le point sur une esthétique des ambiances en cours d'édification et qui travaille à quatre niveaux. Au niveau esthésique: qu'est-ce que l'imperceptible? Et quel est le rôle des formes non visibles? Au niveau épistémique: comment intégrer les diverses connaissances pertinentes mais travaillant trop dans l'exclusive? Au niveau rhétorique : comment s'organisent les composantes d'une ambiance, et comment en nommer les configurations? Au niveau de la compétence esthétique : qui fait une ambiance ? Comment se répartissent création et réception?

\section{INDEX}

Mots-clés: ambiances, environnement sensible, architecture, forme urbaine, perception in situ esthétique du quotidien, formalités d'usage, interdisciplinarité

Keywords: ambiances, sensory environment, architecture, urban forms, in situ perceptions, everyday aesthetics, forms of usage, interdisciplinarity 


\section{AUTHORS}

\section{JEAN-FRANÇOIS AUGOYARD}

Jean François Augoyard (1941)

- Graduate in Philosophy, Sociology, Musicology. Doctor in Urban Planning. Former Research director at the CNRS.

- Founder in 1979 of the "Centre de Recherche sur l'Espace sonore et l'Environnement Urbain" (CRESSON) and in 1992: the CNRS 1563 unit:"Ambiances, Architecture, Urbanités».

Co-founder \& coordinator of the doctoral dept. "Ambiances architecturales et urbaines". Co-founder of the international network <ambiances.net>

Director of the "Ambiances, Ambiance" collection, Ed. À la Croisée, Bernin. (9 books)

- Professor and Invited Professor at many Universities in France (Vincennes, Paris V, Grenoble II, ENSArchitecture de Grenoble) or in the World (Europe, North America, South America, China).

- Main topics of research: perceptions \& actions in urban space, anthropology of sonic space, effects of artistic performances in the city, aesthetics of everyday life; theory of situated ambiances; interdisciplinary methodology.

- 10 books \& articles translated in English, Italian, Spanish, Portuguese \& Japanese. 